\title{
DIMBOA and DIBOA, two naturally occuring benzoxazinoides, cause aneuploidy in a human-derived liver cell line (HepG2) Christoph Buchmann ${ }^{1}$, Armen Nersesyan ${ }^{1}$, Brigitte Kopp ${ }^{2}$, Doris Schauberger ${ }^{2}$, Firouz Darroudi ${ }^{3}$, Tamara Grummt ${ }^{4}$, Georg Krupitza5, Rolf Schulte-Hermann ${ }^{1}$ and Siegfried Knasmüller*1
}

\begin{abstract}
Address: ${ }^{1}$ Institute of Cancer Research, Internal Medicine I, Medical University of Vienna, Austria, ${ }^{2}$ Institute of Pharmacognosy, University of Vienna, Austria, ${ }^{3}$ Department of Toxicogenetics, Leiden University Medical Centre, The Netherlands, ${ }^{4}$ Deutsches Umweltbundesamt Bad Elster, Germany and 5 Institute of Clinical Pathology, Medical University of Vienna, Austria
\end{abstract}

Email: Siegfried Knasmüller* - siegfried.knasmueller@meduniwien.ac.at

* Corresponding author

\author{
from 13th Scientific Symposium of the Austrian Pharmacological Society (APHAR). Joint Meeting with the Austrian Society of Toxicology (ASTOX) and the \\ Hungarian Society for Experimental and Clinical Pharmacology (MFT) \\ Vienna, Austria. 22-24 November 2007 \\ Published: 14 November 2007 \\ BMC Pharmacology 2007, 7(Suppl 2):A75 doi:10.1186/147I-2210-7-S2-A75
}

This abstract is available from: http://www.biomedcentral.com/I47I-22 I0/7/S2/A75

(C) 2007 Buchmann et al; licensee BioMed Central Ltd.

\section{Introduction}

Dihydroxy-7-methoxy-1,4-benzoxazin-3-one (DIMBOA) and 2,4-dihydroxy-1,4-benzoxazin-3-one (DIBOA) are naturally occuring benzoxazinoides (BA) and are found in sprouts of Gramineae. We investigated their genotoxic effects in a human-derived liver cell line (HepG2).

\section{Methods}

The Salmonella/microsome assay (Ames test) was used for pre-screening (TA98, TA100 and YG1024; \pm S9). Juices of wheat and maize sprouts were also tested. The effects on HepG2 were tested with the single cell gel electrophoresis assay (SCGE), the micronucleus assay (MN) and pancentromeric probes $(\mathrm{CP})$ with fluorescence in situ hybridization (FISH).

\section{Results}

In the Ames test DIBOA was positive. Effects in YG1024 were little higher as in TA98. DIMBOA was positive in TA100 only. Addition of S9 led to higher mutagenic activities. The sprout juices were clearly positive, however not due to the BAs. The SCGE assay was negative, but the MN assay was positive (DIMBOA at $>2.5 \mu \mathrm{M}$, DIBOA at $>5$ $\mu \mathrm{M})$. The CP showed $>80 \%$ centromere positive $(\mathrm{C}+)$ micronuclei.

\section{Conclusion}

The slight differences between YG1024 and TA98 indicate that acetylation plays no role in the activation. The BAs can be classified as weak bacterial mutagens. It is unclear why the sprout juices were positive. Due to the results of the assays with HepG2, we tested for aneuploidic effects. This was confirmed by the CP result. Aneuploidy is thought to be a key event in cancer induction and no other aneugenic plant-derived substances of dietary relevance are known. 